\title{
Modified CTAB protocol for RNA extraction from Lemon balm (Melissa officinalis L.)
}

\author{
Leila AMRAEE ${ }^{1}$, Fatemeh RAHMANI ${ }^{1,2}$
}

Received February 23, 2018, accepted January 1, 2020.

Delo je prispelo 23. februarja 2018, sprejeto 1. januarja 2020.

\begin{abstract}
Modified CTAB protocol for RNA extraction from Lemon balm (Melissa officinalis L.)

Abstract: Ribonucleic acid (RNA) quality and integrity are crucial for many studies in plant molecular biology. High-quality RNA extraction from plants with high levels of compounds such as polysaccharides, polyphenols, and other secondary metabolites are problematic. RNA extraction from Lemon balm tissues can be difficult due to the presence of polyphenolic and polysaccharide compounds or can be done by expensive protocols. This study shows improvement of a CTAB-based protocol which allows rapid and easy isolation of high-quality RNA from Lemon balm plant. The RNA obtained is suitable for cDNA synthesis and RT-PCR experiments.
\end{abstract}

Key words: Melissa officinalis; CTAB; RNA; RT-PCR
CTAB protokol za ekstraskcijo RNK iz melise (Melissa officinalis L.)

Izvleček: Kakovost in ohranjenost ribonukleinske kisline (RNK) sta bistveni za mnoge raziskave v molekularni biologiji rastlin. Visoko kakovostni izvlečki RNK iz rastlin z veliko vsebnostjo spojin kot so polisaharidi, polifenoli in drugi sekundarni metaboliti so problematični. Ekstrakcija RNK iz tkiv melise je lahko težavna zaradi prisotnosti polifenolov in polisaharidov ali pa je lahko narejena le $\mathrm{z}$ dragimi protokoli. Raziskava predstavlja izboljšanje protokola na osnovi CTAB, ki omogoča hitro in enostavno izolacijo kvalitetne RNK iz melise. Pridobljena RNK je primerna za cDNK sintezo in RT-PCR poskuse.

Ključne besede: Melissa officinalis; CTAB; RNK; RT-PCR
1 Urmia University, Faculty of Sciences, Department of Biology, Urmia, Iran

2 Corresponding author, e-mail: f.rahmani@urmia.ac.ir 


\section{INTRODUCTION}

The extraction of high quality ribonucleic acid (RNA) is an important step for many studies in plant molecular biology, such as northern blotting, microarray hybridization, both targeted real-time PCR (RTqPCR) analysis and next generation sequencing (NGS) (Gambino et al., 2008; Guerriero et al., 2016). Extraction of RNA in sufficient quantity and quality from the tissues of aromatic, woody, and aquatic plants is particularly challenging, because of high levels of compounds such as polysaccharides, polyphenols, and other secondary metabolites (Gambino et al., 2008; JordonThaden et al., 2015). Phenolic compounds form high molecular weight complexes tend to co-precipitate with RNA by binding to nucleic acids and polysaccharides in the presence of alcohols. Hence, they contaminate the final extract and interfere with subsequent applications (Gambino et al., 2008).

Conventional protocols for RNA isolation usually involve the use of detergents, such as cetyl trimethyl ammonium bromide (CTAB) or sodium dodecyl sulphate (SDS), denaturing organic solvents (phenol and chloroform), reducing agents ( $\beta$-mercaptoethanol and dithiothreitol), or denaturing agents (guanidinium isothiocyanate salts) (Gambino et al., 2008). Methods involving $\mathrm{CTAB}$, initially were developed for pine tree tissues (Chang et al., 1993) and subsequently used to extract RNA from a wide range of polysaccharide- and polyphenol-rich plant tissues (Iandolino et al., 2004; Meisel et al., 2005; Gambino et al., 2008).

Lemon balm is one of the oldest and widely used medicinal plant in the mint family (Lamiaceae), native to Southern Europe, Mediterranean region and northern Iran (Döring et al., 2014; Jalal et al., 2015). It is a perennial herb and a rich source of natural antioxidants (Saraydin et al., 2012). Reports indicated that lemon balm had many beneficial effects such as anti-oxidant, anti-bacterial, anti-viral, anti-inflammatory, sedative, mnemonic improvement, reducing excitability, anxiety, stress, gastrointestinal disorders and sleep disturbance. However, the mechanisms underlying these medicine effects remain largely unknown (Jalal et al., 2015).

Nutritional efficacy testing, based on selected biomarker approaches, do not provide global information while application of microarrays and high-throughput qPCR allows quantification of a large number of biomarkers, and consequently enables evaluation of the global effects of nutrients on cells (Jun et al., 2012). Hence, a clean and intact RNA is important for functional genomic studies (Rubio-Piña \& Zapata-Pérez, 2011).

The aim of this study was to develop an optimized
CTAB-based protocol, to reduce the time and cost of extraction without reducing quality and yield of RNA from polyphenolics and polysaccharide-rich tissues of old lemon balm.

\section{MATERIALS AND METHODS}

\subsection{PLANT SPECIES USED}

Leaf tissues was collected from 3 months old lemon balm plant (Agricultural and Natural Resources and Education Center, West Azerbaijan, Iran) and frozen in liquid nitrogen. Then, leaf samples were transferred to $-80{ }^{\circ} \mathrm{C}$ until analyses. Total RNA was extracted with TRIzol (Sigma Alderich), RNX- plus (Sina Clone) and (CTAB)-based protocol.

\subsection{NUCLEIC ACID EXTRACTION}

\subsection{1 (CTAB)-based protocol}

\subsubsection{Reagents}

Extraction buffer: $2 \%(\mathrm{w} / \mathrm{v})$ CTAB (hexadecyltrimethylammonium bromide), $0.1 \mathrm{M}$ Tris- $\mathrm{Hcl}$ (pH: 8), $1.4 \mathrm{M} \mathrm{NaCl}, 20 \mathrm{mM}$ EDTA (pH: 8), 2 \% PVP (polyvinylpyrrolidone), BME ( $\beta$-mercaptoethanol) (to a final concentration of $10 \%(\mathrm{v} / \mathrm{v})$, added right before use).

Sodium acetate $3 \mathrm{M}$ (pH: 5)

Chloroform/ IAA (isoamyl alcohol) (24/1)

$\mathrm{Phenol} /$ chloroform/ isoamyl alcohol (25/24/1)

$70 \%$ ethanol

RNA/RNase-free water

DNase inactivation reagent

Liquid nitrogen in a Dewar flask

Equipment list

Water bath at $65^{\circ} \mathrm{C}$

Vortexer

24-place centrifuge cooled to $4{ }^{\circ} \mathrm{C}$

Incubator at $37^{\circ} \mathrm{C}$ with orbital shaker

Procedure

1- About 80-100 mg of leaf tissue was ground to a fine powder using liquid nitrogen and transferred into a $2 \mathrm{ml}$ centrifuge tube. Then, $900 \mu \mathrm{l}$ of extraction buffer and $100 \mu \mathrm{l}$ of $\beta$-mercaptoethanol were added. The mixture was shaken for $30 \mathrm{~s}$ and then incubated at $65{ }^{\circ} \mathrm{C}$ for $10 \mathrm{~min}$, inverting the tube 3-4 times every now and then during incubation.

2- Then, $800 \mu \mathrm{l}$ of chloroform was added. The mixture was shaken for $30 \mathrm{~s}$ and centrifuged at $12000 \mathrm{rpm}$ 
for $10 \mathrm{~min}$ at $4{ }^{\circ} \mathrm{C}$. The supernatant was transferred to a new tube.

3- $800 \mu \mathrm{l}$ of phenol/chloroform/ isoamyl alcohol $(25 / 24 / 1)$ was added and shaken for $1 \mathrm{~min}$. Then, the mixture was centrifuged at $12000 \mathrm{rpm}$ for $15 \mathrm{~min}$ at $4{ }^{\circ} \mathrm{C}$ (this step was repeated twice).

4- The supernatant was transferred to a new tube and an equal volume of chloroform/isoamyl alcohol (24/1) was added. Samples were shaken for $30 \mathrm{~s}$ and centrifuged at $12000 \mathrm{rpm}$ for $10 \mathrm{~min}$ at $4^{\circ} \mathrm{C}$.

5- The final supernatant was transferred to a new tube. $1 / 10$ volume of sodium acetate $(3 \mathrm{M}, \mathrm{pH}$ : 5$)$ and equal volume of cool isopropanol were added to the tube, then kept at $-20^{\circ} \mathrm{C}$ for at least $1 \mathrm{~h}$. Next, the samples were centrifuged at $13000 \mathrm{rpm}$ for $15 \mathrm{~min}$ at $4^{\circ} \mathrm{C}$.

6- The pellets were successively washed with $70 \%$ ethanol for one or two times. After a short drying time at room temperature, the pellets were dissolved in 20$50 \mu \mathrm{l}$ of DEPC water.

7- Finally, $1 \mu \mathrm{l}$ of DNase enzyme was added and incubated at $37^{\circ} \mathrm{C}$ for $30 \mathrm{~min}$.

\subsection{ESTIMATION OF RNA QUALITY}

The purified RNA was measured by spectrophotometric analysis (Nanodrop 2000c; Thermo Fisher Scientific, Waltham, USA). Contamination due to proteins and phenol/carbohydrates was determined by recording the OD ratios; $A_{260} /{ }_{280}$ and $A_{260} / 230$, respectively. In order to verify RNA integrity, extracts were fractioned by electrophoresis in a $1.5 \%$ agarose gel, stained with ethidium bromide and visualized in a gel documentation system (InGenius3, Syngene, UK).

\subsection{RT-PCR}

Single-stranded cDNA was synthesized from 500 ng total RNA using reverse transcriptase and oligo (dT), following the manufacturer's protocol (Thermo Scientific). The synthesized cDNA was used in a PCR reaction in order to estimate the expression level of the tubulin gene using following primers: Tubulin-FWD: 5'-GCTTTCAACACCTTCTTCAGTG-3' and Tubulin REV: 5'-CTTTCTCAGCTGAGATCACTG G-3'.

\section{RESULTS AND DISCUSSION}

\subsection{ESTIMATION OF RNA QUALITY}

The isolation of high-quality RNA from enrich polysaccharides and polyphenols plant tissues is quite challenging (Liao et al., 2014). Lemon balm leaves contain secondary metabolites such as, polyphenolic acid (rosmaric acid, trimeric compounds and some flavonoids), terpenoids, carboxylic acid, essential oils, various sugars, golden and pectic materials (Jafarpour \& Fard, 2016) which affect the quality of the isolated RNA. The biosynthesis of secondary metabolites in plants is influenced by season harvesting, growing region, agronomic conditions and type of processing (Wahby, 2016). Therefore, RNA extraction from lemon balm tissues can be difficult due to the presence of these compounds. Polyphenolic compounds (particularly tannins) are readily oxidized to form quinones, which bind irreversibly to nucleic acids and proteins, and may decrease RNA yield, as well as inhibit PCR amplification (Shu et al., 2014). In contrast, polysaccharides can co-precipitate and degrade RNA, constitute the major obstacle of RNA isolation in low ionic strength buffers, and cause the browning effect and make RNA difficult to be dissolved (Shu et al., 2014). In addition, these interfering chemicals severely interfere with RNA-dependent RT and DNA polymerases and cause the RTPCR to fail. Thus, these contaminating substances must be eliminated during RNA isolation (Hou et al., 2011; Ouyang et al., 2014; Sabzevari \& Hosseini, 2014). In this case, successful isolation of intact RNA from tissues rich in polysaccharides and polyphenolic compounds, is a basic requirement for many molecular studies

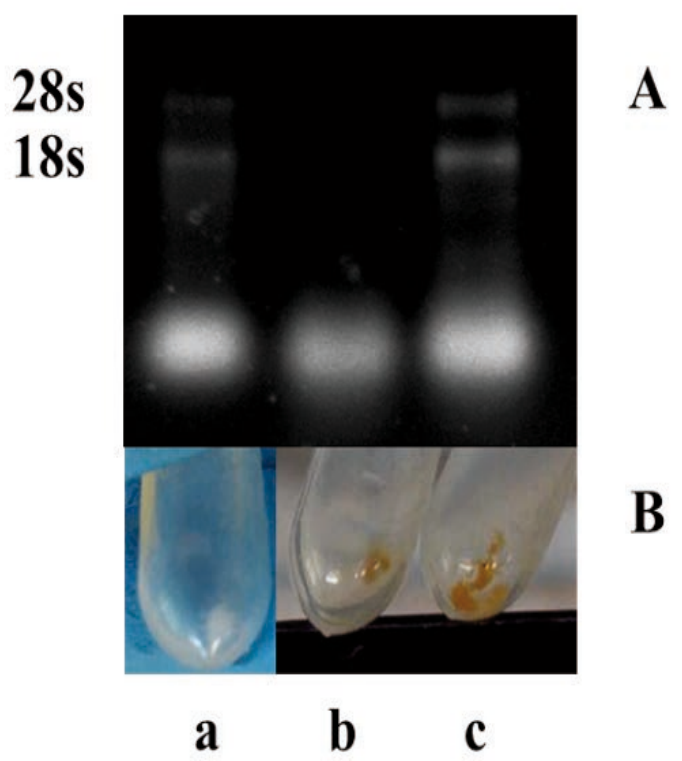

Figure 1: (A): Ethidium bromide agarose gel (1.5\% (w/v)) was used to separate total RNA and (B): pellet of RNA extracted from leaf tissues of three months old lemon balm plant by (a) CTAB; (b) TRIzol and (c) RNX-Plus. 
Table 1: Quality of total RNA isolated from three months old leaves of lemon balm based on three different protocols

\begin{tabular}{lll}
\hline Method & $\mathrm{A}_{260} / 280$ value & $\mathrm{A}_{260} /_{230}$ value \\
\hline CTAB & 1.96 & 1.80 \\
TRIzol & 1.52 & 0.54 \\
RNX-Plus & 1.67 & 0.38 \\
\hline
\end{tabular}

(Hunter \& Reid, 1999; Martínez-Fuentes et al., 2015). The currently commercial kits such as RNeasy, BioZOL and BIOLINE are simple, rapid, non-toxic with good yields of high-quality RNA from plant tissues, but too expensive. Moreover, successful RNA extraction by RNX- Plus and TRIzol from lemon balm plant has only been reported in seedling stage and explants grown in solid MS medium, respectively (Kim et al., 2011; Nasiri-Bezenjani et al., 2014). Upon this status, we tested three different methods (modified CTAB, TRIzol and RNX- Plus) to evaluate the best and effective RNA extraction method from 3 months old lemon balm plant.

In current study, evaluation of quality and quantity of total RNA isolated from three different protocols was done by agarose denatured gel (Figure 1a) and nanodrop (Table 1), respectively. The CTAB method already showed a much better RNA quality than TRIzol and RNX-Plus methods by only visualizing the pellet. The RNA pellet appeared in white color in CTAB method while TRIzol and RNX-Plus methods produced brown colored pellet (Figure 1b). The brown color indicates the presence of carbohydrates, proteins and phenolic compounds mixed with the extracted RNA (Rubio-Piña \& Zapata-Pérez, 2011). In the CTAB method, brown color and contamination (phenolic compounds) were reduced by addition of PVP and high concentrations of $\beta$-mercaptoetanol in the extraction buffer. The PVP strongly binds to the polyphenol compounds through hydrogen bonds, and removes phenolic compounds and secondary metabolites from nucleic acid, also preventing browning effect of polyphenols (Rubio-Piña \& Zapata-Pérez, 2011; Shu et al., 2014). The strong reductant $\beta$-mercaptoetanol is conventionally used at $10 \%(\mathrm{v} / \mathrm{v})$ to inhibit RNase activity and prevent any possible oxidation reactions (Ouyang et al., 2014). On the other hand, chloroform: isoamyl alcohol is used to eliminate remaining phenolic compounds and PVP from solution (Shu et al., 2014; Martínez-Fuentes et al., 2015). Total RNA isolated by modified CTAB and RNX- Plus method showed two bright bands (28S rRNA and 18S rRNA). However, the gel electrophoresis result of TRIzol method revealed no production of clear and bright RNA band, indicating low quantity of RNA.

The $\mathrm{A}_{260} /_{230}$ ratio detected below 0.6 in both TRIzol and RNX-Plus methods (Table 1), representing high con-

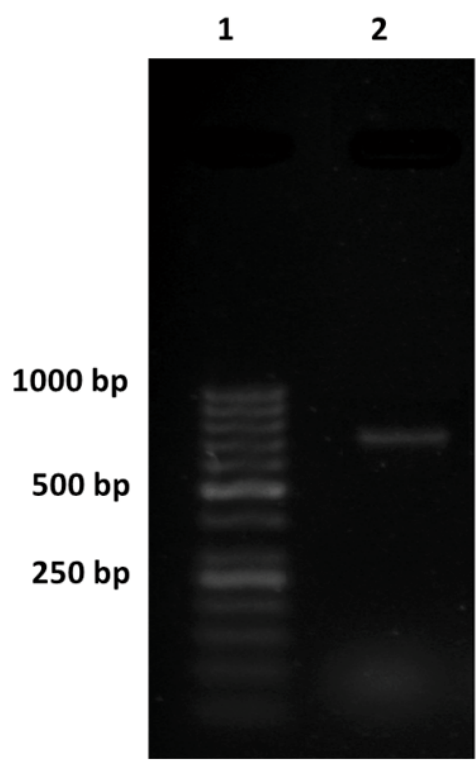

Figure 2: RT- PCR product with tubulin specific primers using total RNA isolated from leaves of three months old lemon balm plant based an CTAB method. Lane 1: 50 bp DNA ladder (Thermo Fisher Scientific), Lane 2: 750 bp amplified Tubulin gene.

tamination with phenolic compounds or polysaccharides and very low molecular grade of RNA (Martínez-Fuentes et al., 2015). It is important to note that RNA solution with $\mathrm{A}_{260} /{ }_{280}$ and $\mathrm{A}_{260} /{ }_{230}$ ratios of 1.8 2.0 corresponds to a high quality (Hou et al., 2011; Martínez-Fuentes et al., 2015). However, CTAB based method produced highly purified RNA with $\mathrm{A}_{260} /{ }_{280}$ and $\mathrm{A}_{260} /{ }_{230}$ ratios of 1.96 and 1.80 , respectively (Table 1).

\subsection{RT-PCR}

RNA sample extracted by the improved CTAB method, was further characterized with RT-PCR using tubulin primers. The results showed amplification of an expected fragment of approximately $750 \mathrm{bp}$ (Figure 2), suggesting high quality of extracted RNA at the molecular level. Due to RNA contamination, reverse transcriptase enzyme will fail to produce cDNA, which consequently, RT-PCR could result in failure to amplify the target sequence (Sabzevari \& Hosseini, 2014). Thus, the successful synthesis of the first-strand CDNA and PCR amplification (Figure 2) clearly shows that the RNA is free of contaminants.

\section{CONCLUSION}

Our results demonstrated that, modified CTAB 
protocol extracted highly qualified RNA from lemon balm old leaves compared to other tested methods. The method is cost effective and may be simply used as an alternative method for RNA isolation from recalcitrant plant tissues.

\section{REFERENCES}

Chang, S., Puryear J., Cairney J. (1993). A simple and efficient method for isolating RNA from pine trees. Plant Molecular Biology Reporter, 11(2), 113-116. https://doi.org/10.1007/ BF02670468

Döring, A.S., Pellegrini, E., Della Batola, M., Nali, C., Lorenzini, G., Petersen, M. (2014). How do background ozone concentrations affect the biosynthesis of rosmarinic acid in $\mathrm{Me}$ lissa officinalis?. Journal of Plant Physiology, 171(5), 35-41. https://doi.org/10.1016/j.jplph.2013.11.005

Gambino, G., Perrone, I., Gribaudo, I. (2008). A rapid and effective method for RNA extraction from different tissues of grapevine and other woody plants. Phytochemical Analysis, 19(6), 520-525. https://doi.org/10.1002/pca.1078

Guerriero, G., Mangeot-Peter, L., Hausman, J.F., Legay, S. (2016). Extraction of high quality RNA from Cannabis sativa bast fibres: A vademecum for molecular biologists. Fibers, 4(3), 23. https://doi.org/10.3390/fib4030023

Hou, P., Xie, Z., Zhang, L., Song, Z., Mi, J., He, Y., Li, Y. (2011). Comparison of three different methods for total RNA extraction from Fritillaria unibracteata, a rare Chinese medicinal plant. Journal of Medicinal Plants Research, 5(13), 2835-2839.

Hunter, D.A., \& Reid, M.S. (1999). A simple and rapid method for isolating high quality RNA from flower petals. In VII International Symposium on Postharvest Physiology of Ornamental Plants, 543, 147-152. https://doi.org/10.17660/ActaHortic.2001.543.18

Iandolino, A.B., Da Silva, F.G., Lim, H., Choi, H., Williams, L.E., Cook, D.R. (2004). High-quality RNA, cDNA, and derived EST libraries from grapevine (Vitis vinifera L.). Plant Molecular Biology Reporter, 22(3), 269-278. https://doi. org/10.1007/BF02773137

Jafarpour, M., \& Fard, A.N. (2016). The effects of aqueous extract of Melissa officinalis on some blood parameters and liver of Oncorhynchus mykiss. Aquaculture, Aquarium, Conservation \& Legislation-International Journal of the Bioflux Society (AACL Bioflux), 9(3). https://doi.org/10.13005/bpj/940

Jalal, Z., El Atki, Y., Lyoussi, B., Abdellaoui, A. (2015). Phytochemistry of the essential oil of Melissa officinalis L. growing wild in Morocco: preventive approach against nosocomial infections. Asian Pacific Journal of Tropical Biomedicine, 5(6), 458-461. https://doi.org/10.1016/j.apjtb.2015.03.003

Jordon-Thaden, I. E., Chanderbali, A. S., Gitzendanner, M. A., Soltis, D. E. (2015). Modified CTAB and TRIzol protocols improve RNA extraction from chemically complex Embryophyta. Applications in Plant Sciences, 3(5), 1400105. https:// doi.org/10.3732/apps.1400105

Jun, H. J., Lee, J. H., Jia, Y., Hoang, M. H., Byun, H., Kim, K. H., Lee, S. J. (2012). Melissa officinalis essential oil reduces plasma triglycerides in human apolipoprotein E2 transgenic mice by inhibiting sterol regulatory element-binding protein-1c-dependent fatty acid synthesis. The Journal of Nutrition, 142(3), 432-440. https://doi.org/10.3945/ jn.111.152538

Kim, J. H., Hossain, A. M., Kim, N. H., Lee, D. H., Lee, H. J. (2011). Identification and functional characterization of the GALACTINOL SYNTHASE (MoGolS1) gene in Melissa officinalis plants. Journal of Applied Biological Chemistry, 54(4), 244-251. https://doi.org/10.3839/jabc.2011.040

Liao, C. M., Li, J., Liu, X. H., Zhang, Y. S. (2014). An effective method for extracting total RNA from Dioscorea opposita Thunb. Genetics and Molecular Research, 13, 462-468. https://doi.org/10.4238/2014.January.21.15

Martínez-Fuentes, A., Mesejo, C., Agustí, M., Reig, C. (2015). Toward a more efficient isolation of total RNA from loquat (Eriobotrya japonica Lindl.) tissues. Fruits, 70(1), 47-51. https://doi.org/10.1051/fruits/2014042

Meisel, L., Fonseca, B., González, S., Baeza-Yates, R., Cambiazo, V., Campos, R., Gonzalez, M., Orellana, A., Retamales, J., Silva, H. (2005). A rapid and efficient method for purifying high quality total RNA from peaches (Prunus persica) for functional genomics analyses. Biological Research, 38(1), 83-88. https://doi.org/10.4067/S0716-97602005000100010

Nasiri-Bezenjani, M. A., Riahi-Madvar, A., Baghizadeh, A., Ahmadi, A. R. (2014). Rosmarinic acid production and expression of tyrosine aminotransferase gene in Melissa officinalis seedlings in response to yeast extract. Journal of Agricultural Science and Technology, 16(4), 921-930.

Ouyang, K., Li, J., Huang, H., Que, Q., Li, P., Chen, X. (2014). A simple method for RNA isolation from various tissues of the tree Neolamarckia cadamba. Biotechnology \& Biotechnological Equipment, 28(6), 1008-1013. https://doi.org/10.1080 /13102818.2014.981086

Rubio-Piña, J. A., \& Zapata-Pérez, O. (2011). Isolation of total RNA from tissues rich in polyphenols and polysaccharides of mangrove plants. Electronic Journal of Biotechnology, 14(5), 11-11. https://doi.org/10.2225/vol14-issue5fulltext-10

Sabzevari, A. G., \& Hosseini, R. (2014). A quick, efficient, and cost-effective method for isolating high-quality total rna from tomato fruits, suitable for molecular biology studies. Preparative Biochemistry and Biotechnology, 44(4), 418431. https://doi.org/10.1080/10826068.2013.833109

Saraydin, S. U., Tuncer, E., Tepe, B., Karadayi, S., Ozer, H., Sen, M., Karadayi, K., Inan, D., Elagoz, S., Polat, Z., Duman, M. (2012). Antitumoral effects of Melissa officinalis on breast cancer in vitro and in vivo. Asian Pacific Journal of Cancer Prevention, 13(6), 2765-2770. https://doi.org/10.7314/ APJCP.2012.13.6.2765

Shu, C., Sun, S., Chen, J., Chen, J., Zhou, E. (2014). Comparison of different methods for total RNA extraction from sclerotia of Rhizoctonia solani. Electronic Journal of Biotechnology, 17(1), 50-54. https://doi.org/10.1016/j.ejbt.2013.12.009

Wahby, M. (2016). Effect of drying period and harvesting times on herb, essential oil content and its constituent's from different parts of Melissa officinalis. Journal of Chemical and Pharmaceutical Research, 8(5), 919-933. 